UDC: 94(477):355.484"Острозький"

Borys Cherkas,

Doctor of Historical Sciences (Dr. Hab. in History), Leading Research Fellow, Institute of History of Ukraine National Academy of Sciences of Ukraine (Ukraine, Kyiv), borysch1976@gmail.com, orcid.org/0000-0002-4201-0659

\title{
THE KOSTIANTYN OSTROZKY'S BATTLES, AS AN EXAMPLE OF THE DUCHY'S REFORMS IN TACTICS
}

Europe - the late Middle Ages. The heyday of the Renaissance begins. The continent is undergoing great changes. The military was greatly influenced by the new changes. First, technology development booming - the invention of gunpowder and firearms is gradually changing the armaments of the armies. Second, social transformation - in Europe, the number of free population increases and the crisis among to of the chivalry begins. Third, economic processes - the trade and the monetary system are booming, the cities are growing and the bourgeois economy is emerging. All this together creates the conditions for the emergence of a new type of the armed forces.

Gradually the main military force was the hired army. Moreover, infantry is gaining more and more influence. Before, for hundreds of years on the continent was ruled by a knightly-feudal militia. In battle, victory was achieved with a blow of a cold weapon. Maneuvering during combat was minimal. The head of the army was more of a leader than a real "general". Now the military leaders have a dilemma - how to manage old and new troops? Where to place infantry and cavalry during the battle? Where and how to put artillery? How to create and move carts (tabir) for transportation of gunpowder and other military equipment. And, most importantly, where to get money. Military leaders are increasingly paying attention to discipline - the first military charters are being written. All these problems were faced by Prince Kostiantyn Ostrozky. And Kostiantyn successfully solved these problems. The military life of Kostiantyn Ostrozky can be divided into two stages. Each stage personified the military doctrine dominated in Europe. So Ostrozky the activity as if illustrates those changes Europe underwented in military affairs. Volyn Army military 


\section{4 | Borys Cherkas}

operations that took part in the late 15th century looked like military force with knight arms. Ostrozky acted as a classic feudal leader in the first campaigns against the Moldovans, Tatars and Muscovites. He acts swiftly, decisively, he tries to destroy the enemy with at one stroke and win! However, the defeat in the Battle near the Vedrosha River and the captivity had a significant impact on Kostiantyn. Already during the war of 1507-1508 Ostrozky acted with caution. He wins by maneuvers. In the battles of 1512 and 1514, Ostrozky applies a new combat tactics. He uses and maneuvers infantry and cavalry and, importantly, skillfully uses the arquebuses's fire and artillery fire. Also 1513-1514 Ostrozky skillfully operates at the operational and strategic level. In 1527 was the last battle and victory of Kostiantyn. In the battle he combined maneuver and cavalry strike. I want to show in my article those elements of changes in tactics that Ostrozky applied during the battles.

Keywords: gunpowder, firearms, the chivalry, military force, the battle, knight arms, arquebuses, artillery, maneuver, cavalry strike.

Борис Черкас, доктор історичних наук, провідний науковий співробітник, Інститут історії України Національної академії наук України

(Україна, Київ),

borysch1976@gmail.com, orcid.org/0000-0002-4201-0659

\section{БИТВИ КНЯЗЯ КОСТЯНТИНА ОСТРОЗЬКОГО, ЯК ПРИКЛАД РЕФОРМ КНЯЗЯ В ТАКТИЦІ}

Пізнє середньовіччя в Європі - це період великих змін. По-перше, бурхливий розвиток технологій - винахід пороху та вогнепальної зброї, зміна озброєння армій. По-друге, соціальна трансформація - в Європі збільшилася кількість вільного населення, почалася криза рицарства. По-третє, економічні процеси - торгівля і грошова система процвітають, зросли міста і з'явилися паростки буржуазної економіки. Особливо ці перетворення позначились на військовій справі. Все це разом створило умови для появи нового типу збройних сил. Поступово основною військовою силою стає наймане військо. Все більшого впливу набуває піхота. У попередні століття на континенті домінувало лицарсько-феодальне ополчення, перемога у бою досягалася ударом холодної зброї. Маневрування під час бою було мінімальним. Глава армії був скоріше вождем, ніж справжнім "генералом". Тепер же у військових керівників виникає дилема - як керувати старими та новими військами? Де розмістити піхоту та кінноту під час бою? Куди і як поставити артилерію? Як створити та перемістити обоз (табір) для перевезення пороху та іншої військової техніки. I, найголовніше, де взяти гроші. Військові керівники все частіше звертають увагу на дисципліну - пишуть перші військові статути. З усіма цими проблемами зіткнувся князь Костянтин Іванович Острозький, які він успішно вирішив. Військове життя Костянтина Івановича Острозького можна розділити на два етапи. Кожен етап уособлював ті 
зміни, що відбувались в Європі. Військові дії Волинської армії, ще наприкінці XV cm. мали вигляд удару-атаки рищарською зброєю. Відповідно, у перших походах проти молдаван, татар і московитів Острозький виступав як класичний феодальний вождь. Він діяв швидко, рішуче, одним ударом намагався знищити ворога і перемогти! Однак поразка в битві біля річки Ведроша та полон справили значний вплив на Костянтина. Вже під час війни 1507-1508 рр. він діяв обережно i, фактично, виграв маневрами. У битвах 1512 та 1514 рр. Острозький застосовував нову тактику бою: використовує та маневрує піхотою та кавалерією та, що важливо, вміло використовує вогонь аркебузів та артилерії. Також 1513-1514 рр. він майстерно діє на оперативному та стратегічному рівні. У 1527 р. відбулась остання переможна битва Костянтина. у цій битві він поєднав маневр та удар кавалерії. Дане дослідження $\epsilon$ спробою показати зміни у тактиці, які застосовував Острозький під час боїв.

Ключові слова: порох, вогнепальна зброя, лицарство, військова сила, битва, лицарська зброя, аркебузи, артилерія, маневр, удар кавалерії.

The military life of Kostiantyn Ostrozky can be divided into two stages. Each stage personified the military doctrine dominated in Europe.

So Ostrozky as if illustrates those changes Europe underwent due to its military doctrine.

The military operations the Volyn army that took part at the end of $\mathrm{XV}$ century, looked as potential firepower with knight arms. Battles of Kopershtyn in winter 1487 (Kronika, 1856: 882; Hrushevskyi, 1993: 328) or battle of brother Mykhailo near Polonny in 1497 (Cherkas, 2014: 59-60) are vivid examples. The elder Ostrozky at that time came from behind and battered the steppe inhabitants with a determined attack. That is why no wonder Kostiantyn Ostrozky used the particular tactics at the first stage of his military career. In 1497 in 1497 the Polish army fought in Moldova The Grand Duchy of Lithuania sent several troops to aid the Poles (Semenova, 2006: 97-99; Papeee, 2006: 144-145). Ostrozky commanded one of these units. K. Ostrozky successfully attacked the Eastern boards of the dukedom after having made a quick raid through the steppe. His troops were attacked by the Crimeans' head by son of khan Muhammad Giray on his way back. The Tatars attacked several times the route formation of Kostiantyn Ostrozky but they were defeated. Tsarevitch was hardly wounded (Kolankowski, 1930: 436). The Moldova march lent an éclat to the duke and recognition of Aleksander Jagiellonczyk imagining and - as the most important - the highest military position in the state: hetman! (Ulianovskyi, 2009: 19). The Moscow war that affected dramatically the future of Kostiantyn as a military leader was the next challenging for the young hetman. 


\section{6 | Borys Cherkas}

In 1500 the Moscow State started the next attack of the Grand Duchy of Lithuania. Ivan III knew the Lithuania was weak so attacked it in three directions (Gerbershteyn, 1988: 66; Taras, 2006: 157-159; Alekseev, 2007: 373-383).

Ostrozky accumulated the troops for defense. But lack of funding and weak discipline among the feudal restricted his ability to keep the forces for a long time.

Ostrozky had time only for a short military operation. Kostiantyn could catch the Moscow military forces near Vedrosha River, Dorogobuzh. The Lithuanian military forces were smaller but regiments of the Grand Duchy of Lithuania had heavy weapon and proper horses as well as better suited for frontal confrontation. Kostiantyn managed to meet the enemy in the location that met his tactical decision. Forests and marshes near the Vedrosha River significantly narrowed the space. Accordingly, the Moscow heads could not use their numerical advantage and reach the Lithuanian flanks with their light horse cavalry. At the same time the latter had to fling back the Muscovites due to determined attack with heavy horse cavalry, especially as the Grand Duchy of Lithuanian intelligence had not found other enemy's reserves. However help for the Muscovites was delivered just after actions of the Lithuanian intelligence agents. And that fact that the help was provided by former nationals of the Grand Duchy of Lithuania, by military forces from Sivershchyna who had very good knowledge of Lithuania military doctrine and technique was the most fatal thing for Ostrozky. July 14, 1500, Kostiantyn Ostrozky started with an offensive his the most unsuccessful battle. The Lithuanians flung the advanced forces of the enemy by the potent firepower and quickly forced the Vedrosha River. According to hetman's plans, his heaviest horse cavalry quite steadily battled down the Muscovites troops one after another. Nevertheless when the Lithuanians have moved further and the forest around got thinner, namely at that moment the reserve forces obtained by the enemy in the evening attacked them from flanks. The Grand Duchy of Lithuania' military forces dispersed. Hetman was taken captive (Gerbershteyn, 1988: 67; Razin, 1999: 321-322; Kazakov, 1998: 58-60).

This defeat did not lessen the attention to K. Ostrozky and his military skills of his contemporaries imaging. Ivan III appointed him as his voivode. Nevertheless have no complete trust to the duke, they keep him near Moscow (Ulianovskyi, 2009: 24-28; Rahauskene, 2014: 30). Only death of this Moscow head let Ostrozky return home and take a hetman title again from Sigismund I the Old (Rahauskene, 2014: 30).

The Moscow captivity had a great influence on the duke the military man. His military operations in the Muscovite-Lithuanian war 1507-1508 have already looked differently. The duke tries to avoid a risk of battle understanding all problems of his troops. He stakes mostly on maneuvering. Subsequently, he manages to force out troops of Mikhail Glinsky quite quickly and finish the war in such a way as necessity for the state for the time being (Krom, 2010: 141-150; Taras, 2006: 168-176). 


\section{The Battle of Vyshnivets}

Sprint 1512, 25-thousand troops of Crimean Khanate attacked Galicia and Volyn.

Poland and the Grand Duchy of Lithuania military forces opposed the aggressors. The allies had up to 6 thou. warriors. The enemy was caught in fields between the City of Vyshnivets and the City of Lopushyn. Control of the military forces was ceded to Ostrozky while holding a military counsel. The council members noted his military skills in war against Tatars. Ostrozky. At dawn April 5 , Ostrozky arrayed the allied military forces. The battle-array consisted of three parts. The right protruded flank consisted of his warriors. The left flank made of Polish regiments was moved a bit back. A small camp made of carts and full of some infantrymen with two guns was located in the center to unable losing connection between two parts of the troops. According to Ostrozky plan, the main thing was not allowing the Tatars to use their quantity advantage and besiege the whole troops. Volyn and Podil regiments headed personally by him had to weaken the enemy with active attacks as well as gradually lead the Tatars for being attacked by Polish heavy horse cavalry for this purpose. The complete battle was continuous attacks and counterattacks. Several times Ostrozky led the Tatars under gun and infantry rifles shooting due to a successful maneuver. The day end Polish horse cavalry hardly rammed the right flank of the enemy when the battle was about to fail. The Crimea Khanate troops dispersed and fled (Cherkas, 2003: 520-521; Cherkas, 2008: 28-29).

As if the Battle of Orsha combined Ostrozky's actions in 1507-1508 and in 1512. On September 8, 1514 the troops of the Grand Duchy of Lithuania and the allies from Poland thoroughly defeated the Muscovite army in the Battle of Orsha. Duke K. I. Ostrozky was in command of victorious troops. The Ukrainian regiments of Volyn and Podil lands were a basis and backbone of his army. Kyiv regiments carried out diverting raids together with Crimean Tatars in the south (Aktyi, 1848: 327-328; Cherkas, 2006: 45, 73). During previous wars the most of the Polish and Lithuanian gonfalons also fought together with the Ukrainians in the south against the Turks and Tatars that ensured the unity of subunits and troops' responsiveness to command as a whole. For his time the decisions and actions of Ostrozky were innovative and unique that is what ensured not only victory but also astonishment and admiration of contemporaries. At first the duke performed a quick march during which they crossed several muskeg streams (the enemy did not believe that with foot troops, artillery arms and baggage train the subunits of Ostrozky can go so swiftly) and by prompt attacks his army defeated some Muscovite units. Further the duke properly chose battlefield in order to fully use a specific character of his troops and to level out a superior manpower of the enemy. Beforehand, just steps from the enemy, they carried out a forced crossing of the Dnipro River over the launched bridges (constructions from floats and empty barrels served as pontoons). On the battlefield Ostrozky trained the troops 
according to his own battle order that beforehand he successfully applied in 1512 in the Battle of Vyshnivets. The regiments were laterally located in two lines. The intervals were kept between subunits. During battling the duke carried out maneuvering by means of gonfalons concentrating them in the threat corridors. As a result the Muscovite troops were defeated in detail (Kazakov, 2018: 315334; Razin, 1999: 351-353; Dróźdź, 2000: 193-202). It stands to mention a proper use of artillery. This is because it was rather young weapon, and commanders broke their heads over that how to use it during the battlefields. The operating site was chosen rather effectually: accesses were covered with adverse terrain, and cannons were masked with bushes. As a result, during the battle the cannons first hit at some point the high-density forward dispositions of enemy cavalry and then they brought down rear-based units. For those times rear-based position was considered to be safe position therefore the incoming heavy bullets caused the panic and escape of the enemy (Gerbershteyn, 1988: 70). As a whole the main military achievement in the Battle of Orsha was that Ostrozky succeeded to encircle and destroy the best subunits of the enemy - the most voivodes and several thousands of noblemen died or were captured. So, notwithstanding Muscovy still had a lot of military forces, however they could not conduct fullscale offensive or commence direct field battles.

In the south Ostrozky fought the battles against constant invasions of nomads. Thus, in 1516 he defeated the unit of Gemmet Giray - nephew of khan. As Muscovite ambassadors wrote, among those who returned many wounded soldiers were (Pamyatniki, 1895: 293; Cherkas, 2006: 101). In 1518 son of khan Bahadir Geray was defeated by Ostrozky in Volyn (Kronika, 1856: 1004; Kromer, 1982: 118; Pamyatniki, 1895: 514, 607; Cherkas, 2006: 120-121). It should be noted that such battles were much more however the sources documented first of all those ones where Kostiantyn opposed the representatives of ruling house of the Crimea.

In August 1519 the Battle of Sokal was with opposite scenario than it was during the Battle of Vyshnivets. At first Ostrozky managed to conduct an integration of Polish and Lithuanian subunits. As well Kostiantyn could pursue the Crimean troops and force a battle for the enemy. However, a part of feudal lords, first of all young people, refused to recognize the command control of Ostrozky. At dawn of August 2 these feudal lords, without notice of Kostiantyn and other heads, commenced an attack. As a result, the Crimean commander Bahadir Geray could defeat the attacking army in detail. Ostrozky kept wits and quickly collected the remnants of the army. After that Kostiantyn avoided the encirclement and retreated with a rapid maneuver (Litvin, 1994: 67-68; Pułaski, 1898: 316; Kromer, 1982: 123; Zygmunt, 1991: 12; Cherkas, 2006: 125-126).

The Battle of Olshanitsa. In the summer of 1526 the units of the Tatar cavalry began to disturb the marchlands of the Grand Duchy of Lithuania. At the end of the year the big Crimean troops conducted an attack, directing it to Volyn 
and Polissia, near Pinsk (AGAD, Arh Radz, Dz. XI, Sygn. 17, S. 24.). The Tatars were approximately 10 thousand. Using frozen rivers and bogs, they could reach far away. The contemporaries noted that it was deep snow and irresistible frost. Ostrozky quickly collected the troops consisted of famous heroes of wars against the Muscovites and Tatars. The following prominent persons were here: princes Slutsky, Sanguszko, Vyshnevetsky and Czartoryski, Radziwill, Nemyrovych, Dashkovych and others. The total number of soldiers of the Grand Duchy of Lithuania was 3.5 thous.

The pursuit was very dramatic. At first the duke searched the Tatar way. And after he got on the track in the big daytime marches, he commences intercept. In order to cut off the accesses to the Dnipro River, Ostrozky send there 1.5 thousand unit headed by the prince Yu. Slutsky. O. Dashkovych. Already in Cherkasy Region Ostrozky saw the left camps of nomads. In these camps the Ukrainians found chewed skeletons of hundreds of eaten horses. The soldiers of Ostrozky, going day and night, could pursue the enemy on the Olshanytsia River outside Kaniv early in February.

Hetman came to the enemy camp at night however he was under the necessity of giving rest for the horses. The very battle he delivered at dawn of the next day. At the same time, Ostrozky attacked the Tatars when they let the horses go to grass, cut (cattle) and feasted and then went to rest. Accordingly, the duke attacked the Tatars in the early dawn and performed the debellation for them. At first the soldiers of Ostrozky in the Battle of Olshanitsa seized the Tatar horses and forced them to fight on foot that was difficult to do because of deep snow. The main Crimean troops were quickly dispersed. The liberation of captives, who attacked the enemy in the rear, also played a major role in this situation. However, own wife of head of Perekopskaya residents could arrange a defense and maintained a fierce resistance for a full day. But they were also defeated. The resounding defeat of the Crimean Tatars was the consequence of the battle. Not killed persons, who broke clear of the encirclement, were intercepted between Kaniv and Cherkasy by the unit of Yu. Slutsky and O. Dashkovych. Many children were liberated and in order to rescue them the landlords should get off the horses and the kids were set on horsebacks. Duke Kostiantyn Ostrozky together with 700 captive Tatars came to the king to Krakow (Cherkas, 2008a: 53-59).

Ostrozky became a single commander-in-chief who was arranged a triumph in Vilnia and Krakow. It was the last victory of K. Ostrozky, a short time later he died. During his life, according to papal legate Jakub Piso, the duke had 33 victories over the Tatars. At the same time, 63 victories in total were specified on the sarcophagus of Kostiantyn Iwanowycz! 


\section{ARCHIVES}

AGAD - Archiwum Głuwny Akt Dawnych w Warszawie [The Central Archive of Ancient Documents in Warsaw].

\section{BIBLIOGRAPHY}

Акты относящиеся к истории Западной России, собранные и изданные Археографическою комиссиею: в $5 \mathrm{~m}$. Санкт-Петербург, 1848: T.II 1506 по $1544,440$.

Алексеев Ю. Походы русских воск при Иване III. Санкт-Петербург: СанктПетербургский государственный университет, 2007, 462.

Герберштейн С. Записки о Московиии. Пер. с нем. А. И. Малеина, А. В. Назаренко. Москва: Издательство Московского университета, 1988, 430.

Грушевський М. С. Історія України-Руси: В 11 m., 12 кн. Київ: Наукова думка, 1993, т IV: XIV-XVI віки - відносини політичні, 535.

Казаков А. Оправдывая поражение: Оршанская битва 1514 г. глазами летописцев. Україна в Центрально-Східній Європі. Київ: Інститут історії України НАН України, 2018, вип. 18, 315-334.

Казаков О. Битва на річці Ведроші 14 липня 1500 р. Украӥнський історичний журнал. 1998, № 5, 52-63.

Кром М. Меж Русью и Литвой. Пограничные земли в системе русско-литовских отношений конца XV - первой трети XVI в. Москва: Квадрига, 2010, 318.

Литвин Михалон. $O$ нравах татар, литовцев и московитян. Пер. В. И. Матузовой. Москва: Издательство Московского университета, 1994, 150.

Памятники дипломатических сношений Московского государства с Крымом, Нагаями и Турциею. T. II. Изданы под редакцией Г. Ф. Карпова и Г. Ф. Штендмана. Сборник Императорского Русского исторического общества. Санкт-Петербург: Товарищество «Печатня С. П. Яковлева», 1895, т. 95, XIX+706+108.

Рагаускене Р. Політична кар'єра Костянтина Острозького в часи правління Сигізмунда Старого. Князі Острозькі. Київ: Балтія-Друк, 2014. 30-39.

Разин Е. История Военного искусства. Москва-Санкт-Петербург: Полигон, 1999, т. 2, 654.

Семенова Л. Княжества Валахия и Молдавия, конец XIV - начало ХІХ. Очерки внешнеполитической истории. Москва: Индрик, 2006, 400.

Тарас А. Войны Московской Руси с Великим княжеством Литовским и Речью Посполитой в XIV-XVII в8. Москва-Минск: Аст-Харвест, 2006, 799.

Уляновський В. «Славний для всіх часів чоловік»: князь Костянтин Іванович Острозький. Острог: Острозька академія, 2009, 167.

Черкас Б. Вишневецька битва. Волонтер. 2008, № 2, 28-29. 
Черкас Б. Вишнівецька битва. Енциклопедія історії України. Київ: Наукова думка, 2003, т. 1, 520-521.

Черкас Б. Військова кар'єра Костянтина Острозького і оборона рубежів Литовсько-Руської держави (кінець XV - перша третина XVI ст.). Князі Острозькі. Київ: Балтія-Друк, 2014, 59-60.

Черкас Б. Ольшаницька битва 1527 р. Україна в Центрально-Східній Європі. Київ: Інститут історії України НАН України, 2008, вип. 8, 53-59.

Черкас Б. Україна в політичних відносинах Великого князівства Литовського з Кримським ханатом (1515-1540). Київ: Інститут історії України НАН України, 2006, 244.

Dróźdź P. Orsza 1514. Warszawa: Bellona, 2000, 214.

Kolankowski L. Dzieze Wielkiego Księstwa Litewskiego za Jagiellonow, m 1 13771499. Warszawa: Z drukarni zakładu narodowego imienia Ossolińskich, 1930, IX+474.

Kronika Marcina Bielskiego. Wydanie Kazimierza Józefa Turowskiego. Sanok: Nakład i druk Karola Pollaka, 1856, т II (kn. IV, V), II+701+1222.

Kromer Marcin. Mowa na pogrzebie Zygmunta I oraz o pochodzeniu I o dzieash polakow. Ksiegi XXIX I XXX. Wstęp, przekł. i oprac. J. Starnawski. Olsztyn: Pojezierze, 1982, XXXI+224.

Papèe F. Jan Olbracht. Kraków: Universitas, 2006, 243.

Pułaski K. Machmet - Girej chan Tatarow perekopskich i stosunki jego s Polska (1515-1523). Szkic i poszukiwania historyczne. Serja druga. Petersburg: Nakładem księgarni K. Grendyshyńskiego, 1898, 283-351.

Zygmunt Boras. Poczet hetmanow polskich. Cz. 1. Poznan: PRIMA, 1991, 80.

\section{REFERENCES}

Aktyi, 1848 - Aktyi otnosyaschiesya k istorii Zapadnoy Rossii, sobrannyie i izdannyie Arheograficheskoyu komissieyu: $v 5$ t. (Vol. II). Sankt-Peterburg. [in Russian]. Alekseev, 2007 - Alekseev, Yu. (2007). Pohodyi russkih vosk pri Ivane III. SanktPeterburg: Sankt-Peterburgskiy gosudarstvennyiy universitet. [in Russian].

Cherkas, 2003 - Cherkas, B. (2003). Vyshnivetska bytva. Entsyklopediia istorii Ukrainy (Vol. 1). Kyiv: Naukova dumka, 520-521. [in Ukrainian].

Cherkas, 2006 - Cherkas, B. (2006). Ukraina v politychnykh vidnosynakh Velykoho kniazivstva Lytovskoho z Krymskym khanatom (1515-1540). Kyiv: Instytut istorii Ukrainy NAN Ukrainy. [in Ukrainian].

Cherkas, 2008 - Cherkas, B. (2008). Vyshnevetska bytva. Volonter, 2, 28-29. [in Ukrainian].

Cherkas, 2008a - Cherkas, B. (2008). Olshanytska bytva 1527 r. Ukraina v Tsentralno-Skhidnii Yevropi, (8), 53-59. [in Ukrainian].

Cherkas, 2014 - Cherkas, B. (2014). Viiskova kariera Kostiantyna Ostrozkoho i oborona rubezhiv Lytovsko-Ruskoi derzhavy (kinets XV - persha tretyna XVIst.). Kniazi Ostrozki. Kyiv: Baltiia-Druk, 59-60. [in Ukrainian]. 
Dróźdź, 2000 - Dróźdź, P. (2000). Orsza 1514. Warszawa: Bellona. [in Polish]. Gerbershteyn, 1988 - Gerbershteyn, S. (1988). Zapiski o Moskoviii. Moskva: Izdatelstvo Moskovskogo universiteta. [in Russian].

Hrushevskyi, 1993 - Hrushevskyi, M. (1993). Istoriia Ukrainy-Rusy (Vol. 4: XIVXVI viky - vidnosyny politychni). Kyiv: Naukova dumka. [in Ukrainian].

Kazakov, 1998 - Kazakov, O. (1998). Bytva na richtsi Vedroshi 14 lypnia 1500 r. Ukrainskyi istorychnyi zhurnal, 5, 52-63. [in Ukrainian].

Kazakov, 2018 - Kazakov, A. (2018). Opravdyivaya porazhenie: Orshanskaya bitva 1514 g. glazami letopistsev. Ukraina v Tsentralno-Skhidnii Yevropi, (18), 315-334. [in Russian].

Kolankowski, 1930 - Kolankowski, L. (1930). Dzieze Wielkiego Księstwa Litewskiego za Jagiellonow, $m 1$ 1377-1499. Warszawa: Z drukarni zakładu narodowego imienia Ossolińskich. [in Polish].

Krom, 2010 - Krom, M. (2010). Mezh Rusyu i Litvoy. Pogranichnyie zemli v sisteme russko-litovskih otnosheniy kontsa XV - pervoy treti XVI v. Moskva: Kvadriga. [in Russian].

Kromer, 1982 - Kromer, Marcin. (1982). Mowa na pogrzebie Zygmunta I oraz o pochodzeniu I o dzieash polakow. Ksiegi XXIXI XXX. Olsztyn: Pojezierze. [in Polish].

Kronika, 1856 - Kazimierz, J. (Ed.). (1856). Kronika Marcina Bielskiego. Wydanie Kazimierza Józefa Turowskiego (Vol. II (IV, V)). Sanok: Nakład i druk Karola Pollaka. [in Polish].

Litvin, 1994 - Litvin, Mihalon (1994). O nravah tatar, litovtsev i moskovityan. Moskva: Izdatelstvo Moskovskogo universiteta. [in Russian].

Pamyatniki, 1895 - Karpova, G. \& Shtendmana, G. (Ed.). (1895). Pamyatniki diplomaticheskih snosheniy Moskovskogo gosudarstva s Kryimom, Nagayami $i$ Turtsieyu. T. II. Sbornik Imperatorskogo Russkogo istoricheskogo obschestva (Vol. 95). Tovarischestvo «Pechatnya S. P. Yakovleva». [in Russian].

Papėe, 2006 - Papėe, F. (2006). Jan Olbracht. Krakòw: Universitas. [in Polish].

Pułaski, 1898 - Pułaski K. (1898). Machmet - Girej chan Tatarow perekopskich i stosunki jego s Polska (1515-1523). Szkic i poszukiwania historyczne. Serja druga. Petersburg: Nakładem księgarni K. Grendyshyńskiego, 283-351. [in Polish].

Rahauskene, 2014 - Rahauskene, R. (2014). Politychna kariera Kostiantyna Ostrozkoho v chasy pravlinnia Syhizmunda Staroho. Kniazi Ostrozki. Kyiv: Baltiia-Druk, 30-39. [in Ukrainian].

Razin, 1999 - Razin, E. (1999). Istoriya voennogo iskusstva, v 3-h t. (Vol. 2: Istoriya voennogo iskusstva VI-XVI vv.). Sankt-Peterburg: 000 «Izdatelstvo Poligon». [in Russian].

Semenova, 2006 - Semenova, L. (2006). Knyazhestva Valahiya i Moldaviya, konets XIV - nachalo XIX. Ocherki vneshnepoliticheskoy istorii. Moskva: Indrik. [in Russian].

Taras, 2006 - Taras, A. (2006). Voynyi Moskovskoy Rusi s Velikim knyazhestvom Litovskim i Rechyu Pospolitoy v XIV-XVII vv. Moskva-Minsk: Ast-Harvest. [in Russian]. 